\title{
GON4L Gene
}

National Cancer Institute

\section{Source}

National Cancer Institute. GON4L Gene. NCI Thesaurus. Code C132120.

This gene may play a role in the negative regulation of gene transcription. 